\title{
PARAPLEGIA IN NEW ZEALAND
}

By A. Rowatt Brown, M.B., Ch.B., D.Phys.Med.

NEw ZEALAND, with a population of $2,533,420$, has a relatively high incidence of traumatic paraplegia owing, in part, to the increasing use of tractors in agricultural, work and also to the large number of cars owned by the populace (I to 3). It has been impossible to get details of the level of the lesions in cases of spinal injury, but the following table prepared by the Health Department enumerates those who were in hospital during the years I957 to I96I (table I). In the second table are included all cases of paraplegia, from whatever cause, which were known to the authorities in the year 1959 (table II). These have been separated into residents of the North Island (population I,775, I46) from those living in the South Island (population 758,273).

TABLE I

Paralysis caused by Injuries to the Spine and/or Spinal Cord

\begin{tabular}{|c|c|c|c|c|}
\hline & $\begin{array}{r}\text { Gr } \\
\text { Excluding }\end{array}$ & $\begin{array}{l}\text { P I } \\
\text { admissions }\end{array}$ & With readmi & $\begin{array}{l}\text { JP II } \\
\text { sions included }\end{array}$ \\
\hline \multirow[t]{2}{*}{ I957 } & $\begin{array}{l}M \\
F\end{array}$ & $\begin{array}{r}22 \\
4\end{array}$ & $\begin{array}{l}\mathrm{M} \\
\mathrm{F}\end{array}$ & $\begin{array}{l}44 \\
\text { I I }\end{array}$ \\
\hline & $\mathrm{T}$ & 26 & $\mathrm{~T}$ & 55 \\
\hline \multirow[t]{2}{*}{1958} & $\begin{array}{l}M \\
F\end{array}$ & $\begin{array}{r}18 \\
2\end{array}$ & $\begin{array}{l}M \\
\mathrm{~F}\end{array}$ & $\begin{array}{r}50 \\
3\end{array}$ \\
\hline & $\mathrm{T}$ & 20 & $\mathrm{~T}$ & 53 \\
\hline \multirow[t]{2}{*}{1959} & $\begin{array}{l}M \\
F\end{array}$ & $\begin{array}{r}20 \\
3\end{array}$ & $\begin{array}{l}\mathrm{M} \\
\mathrm{F}\end{array}$ & $\begin{array}{r}37 \\
7\end{array}$ \\
\hline & $\mathrm{T}$ & 23 & $\mathrm{~T}$ & 44 \\
\hline \multirow[t]{2}{*}{ I 960} & $\begin{array}{l}M \\
\mathrm{~F}\end{array}$ & $\begin{array}{r}\text { I } 4 \\
4\end{array}$ & $\begin{array}{l}\mathrm{M} \\
\mathrm{F}\end{array}$ & $\begin{array}{r}22 \\
7\end{array}$ \\
\hline & $\mathrm{T}$ & 18 & $\mathrm{~T}$ & 29 \\
\hline \multirow[t]{2}{*}{ I96I } & $\begin{array}{l}\mathrm{M} \\
\mathrm{F}\end{array}$ & $\begin{array}{r}13 \\
5\end{array}$ & $\begin{array}{l}M \\
F\end{array}$ & $\begin{array}{r}25 \\
8\end{array}$ \\
\hline & $\mathrm{T}$ & I8 & $\mathrm{T}$ & 33 \\
\hline $\begin{array}{l}\text { Total all } \\
\text { Cases }\end{array}$ & $\begin{array}{l}M \\
F\end{array}$ & $\begin{array}{l}87 \\
\text { I } 8\end{array}$ & $\begin{array}{l}\mathrm{M} \\
\mathrm{F}\end{array}$ & $\begin{array}{r}178 \\
35\end{array}$ \\
\hline
\end{tabular}




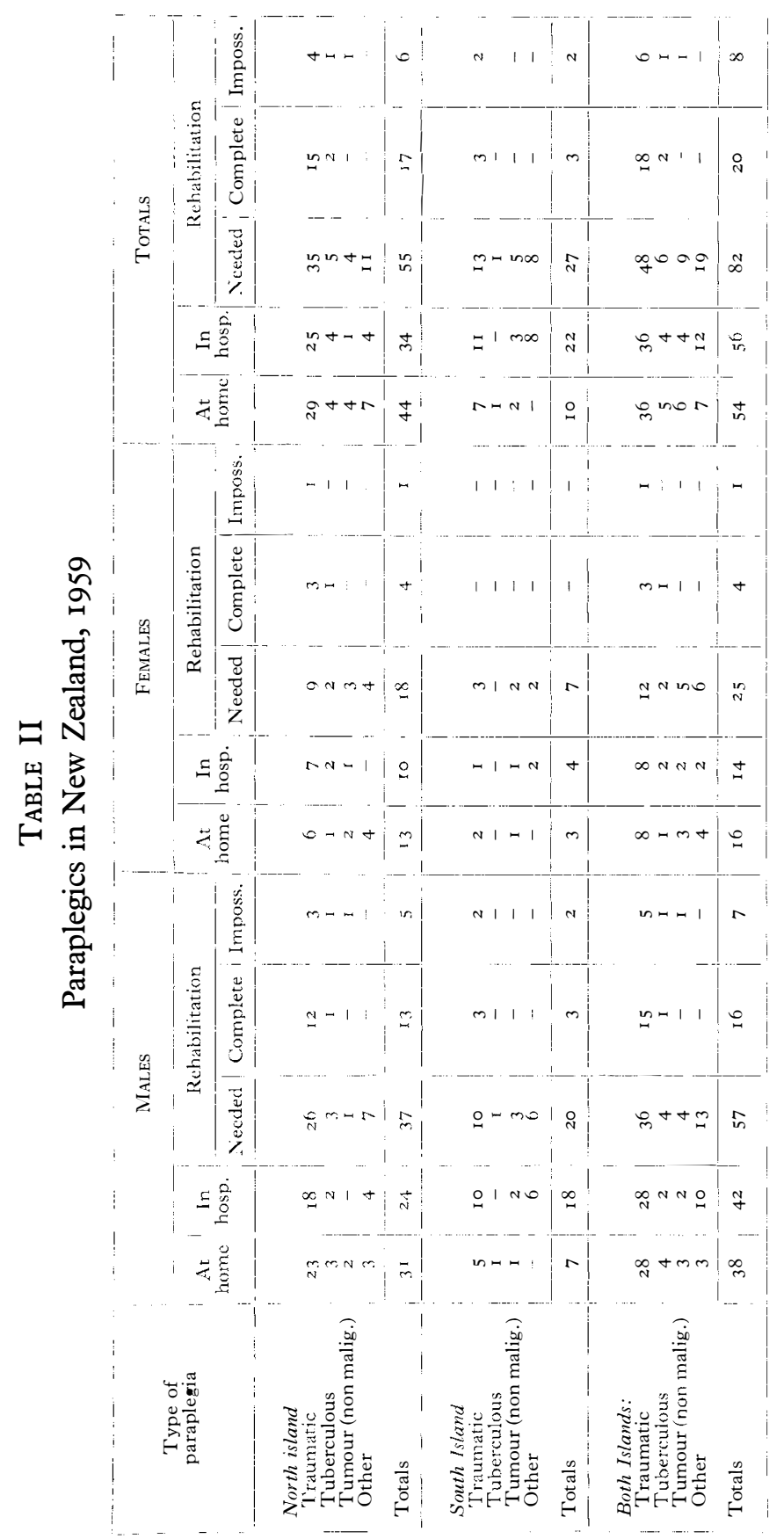


Up to the present time patients admitted to hospital suffering from such spinal conditions have been under the care of General Surgeons, Orthopaedic Surgeons and Neuro-surgeons, generally in the hospitals in the larger centres and, with increasing awareness of the special care required for such patients, there has been a consequent improvement in the long-term results obtained. Following a Seminar on Rehabilitation which was held in 1958 the Inter-Departmental Committee on Civilian Rehabilitation appointed by the Department of Health met and recommended that two 'Paraplegic Units' should be set up, one for the North Island in Aukland and one for the South Island in Christchurch.

At present, in Auckland (population 55 1,546 ), we receive only a proportion of the North Island patients and they are admitted either to the Neuro-surgical Unit or the Orthopaedic Hospital. Orthopaedic, Genito-Urinary and Neuro- Surgeons are, of course, integral members of the team, and those of us who are concerned with Physical medicine and Rehabilitation are intimately associated with the daily programme from the outset. All those who are in control of the cases are aware of the modern methods employed overseas in the care of paraplegics but, owing to constantly changing nursing personnel, it has not always been possible to have instructions carried out in meticulous detail.

During the last five years those suffering from lower spinal cord lesions, in addition to patients with partial lesions at a higher level, have been treated in our Civilian Rehabilitation Centre and a satisfactory proportion are now earning their daily living in industry. In 1962 two of our paraplegics attended the First Paraplegic Commonwealth Games at Perth, Western Australia, and returned with two Gold Medals and one Bronze Medal between them.

The planning for a residential unit of 30 beds in the North Island is well under way and it is to be built almost immediately, and adjacent to the Rehabilitation Centre near Auckland. The extended treatment facilities will be shared by the patients from both. So far no official staff appointment has been made.

Planning for the South Island Spinal Injuries' Centre has not progressed far since first discussed in 1960 as the report of an Operational Research Unit is awaited. The present position is that a Director (Urologist), a Neurologist and an Orthopaedic Surgeon have been appointed and a Nursing Sister has spent six months at Perth in Mr Bedbrook's Unit.

When one considers that New Zealand has only a total population of just over two and a half million and that it is a little more than 100 years since development of the country began, hospital services are well up to overseas standards and the provision of centres to deal with cases of spinal cord injury and disease will fill a long-felt gap in treatment facilities. 